\title{
Epidemiologic and clinical characteristics of 3334 cases with pre-diagnosis coronavirus disease - 2019 (COVID-19) in Turkey
}

\author{
Nur Simsek Yurt ${ }^{1}$, Metin Ocak ${ }^{2}$, and Yusuf Can Yurt ${ }^{2}$ \\ ${ }^{1}$ Samsun Education and Research Hospital \\ ${ }^{2}$ Gazi State Hospital
}

February 1, 2021

\begin{abstract}
Introduction: As COVID-19 disease has rapidly spread across the world, its impact has grown with increasing number of cases and mortality rate in Turkey. Aim: The aim of this study is to examine epidemiologic and clinical features of the patients that admitted to the hospital with the pre-diagnosis of coronavirus disease-2019 (COVID-19) in Turkey. Method: In this retrospective study, epidemiologic and clinical features, laboratory findings, radiologic features, therapeutic approaches and survival conditions of the patients with the pre-diagnosis of COVID-19 from March 11th to June 30th, 2020. The all data of the cases were compared in 4 groups: 1st group for the confirmed cases reverse transcriptase polymerase chain reaction (RT-PCR) +, chest computed tomography $(\mathrm{CT})+$, 2nd group for the clinically diagnosed cases (RT-PCR- CT + ), 3rd group for the mild and asymptomatic cases (RT-PCR + CT-), 4th group for the suspected cases (RT-PCR - CT -). Post-hoc analysis was performed to evaluate the differences among the groups. Results: In total, 3334 patients with the pre-diagnosis of COVID-19 admitted to the emergency department. Based on the post-hoc analyses, significant differences were found among the four groups in terms of their test results of leucocytes, hemoglobin, platelets, neutrophils, urea and C-reactive protein (CRP) (p<0.001). Furthermore, the factors of age groups, hospitalization, intensive care follow-up and mortality rate of the four groups showed a significant difference among the groups $(\mathrm{p}=0.001)$. Conclusion: Mean of leucocytes, neutrophile and platelet values of the patients with tested positive for the RT-PCR was found lower compared to the ones with tested negative for the RT-PCR. Mean of CRP values was found higher in patients with lung involvement compared to other patient groups.
\end{abstract}

\section{Hosted file}

COVID-19 INT.pdf available at https://authorea.com/users/393083/articles/506803epidemiologic-and-clinical-characteristics-of-3334-cases-with-pre-diagnosis-coronavirusdisease-2019-covid-19-in-turkey

\section{Hosted file}

TABLES.pdf available at https://authorea.com/users/393083/articles/506803-epidemiologicand-clinical-characteristics-of-3334-cases-with-pre-diagnosis-coronavirus-disease-2019covid-19-in-turkey

\section{Hosted file}

FIG.pdf available at https://authorea.com/users/393083/articles/506803-epidemiologic-andclinical-characteristics-of-3334-cases-with-pre-diagnosis-coronavirus-disease-2019covid-19-in-turkey 